Accordingly, he stressed the importance of insisting that the general account given in this way should be intelligible to a sufficient number of persons. Sir William also queried whether it is necessary that the Transactions and Proceedings of the Royal Society should contain as much as they do at present. When a new departure in experiment or theory is made and a new fact discovered or a new co-relation, it is right that a careful and complete explanation should be given, and if it is not too long, it is excellent that it should appear in the Proceedings. If, however, the novelty leads, as it often does, to a steady output of observation, extension, confirmation and illustration, many figures and bulky tables, complete publication to the world might become unnecessary. The scientific world requires a general account of progress made, so that its bearing may be clear. The Proceedings should accordingly contain papers of original discovery or fresh departure, but as regards continuation papers, as they may be called, properly written summaries should be enough.

\section{Co-operation in Research}

INTERNATIONAL co-operation in scientific research was also discussed in appreciative terms by Sir William Bragg, and he referred to a letter received from Dr. Bosch, president of the Kaiser Wilhelm Gesellschaft, inviting the co-operation of the Royal Society in some scientific enterprise which would advance science and at the same time promote understanding and good will, in which an exchange of visits between representatives of the Kaiser Wilhelm Gesellschaft and the Royal Society was suggested.

\section{National Registration for Man-Power}

IN the House of Commons, on December 1, Sir John Anderson, Lord Privy Seal, outlined the Government's scheme for organizing the national resources in the service of the State. The plan involves : an immediate voluntary register of manand woman-power throughout the kingdom; the publication of a handbook written in simple language as a guide to be sent to every household; a coordinated campaign of recruiting for the Services; further development of training facilities for new volunteers; making preparations for compiling in the minimum length of time a universal register under compulsory powers in the event of war. The scheme received general approval from the House. Though the time is not propitious for considering the scheme from the particular point of view of the scientific worker (further details must be known before this can be done), it is gratifying to think that embodied in the scheme is the possibility of the man of science being given the opportunity to give the State of his best (see NATURE of October 15), that is, not as a "military subordinate", but in a position where he has "a chance to use his imagination and knowledge co-ordinated with that of his fellow scientific workers and technicians, to criticize and direct, in so far as he is competent, the character of operations". Thus, and only thus, can science be expected to contribute its full share to Sir John's scheme for ensuring that our man-power and woman- power are organized in the most effective and practical way for the voluntary service of the State.

A FULL list is also to be prepared of all the key occupations which would become so essential to the nation in mobilizing for defence. In addition, special arrangements are being made for the compilation of separate registers of persons possessing exceptional professional or technical qualifications. Many of the scientific and technical institutions, we understand, have already taken steps to compile such registers, and these will be available to the Government when required. These registers, together with the records already available of men included in the special list of vital occupations, will constitute the National Voluntary Register. In the last War, many specially qualified men, including men of science, were engaged in the Services at posts which could have been just as ably, if not even more ably, filled by men with less specialized training. The National Voluntary Register will go far in preventing such a waste of man-power in the event of another war. The Government's action in building up its scheme on a voluntary basis rather than resorting to compulsion, at any rate during peace time, follows true democratic principles and is therefore commendable. Any doubts over this point of view should be allayed by Sir John's statement that these precautionary steps taken now will make it possible to compile a compulsory register within three weeks if necessary. In the event of war, of course, it would be necessary to survey and marshal our resources as a whole. The voluntary register would not then be enough, and it would become necessary to compile a universal register under compulsion. To be effective, however, such a register must be up to date, and this condition can be satisfied only if it is compiled at the time when the occasion for its use arises.

\section{Indian Cultural Studies}

IN the discussion which followed Mr. Barger's lecture at the Royal Society of Arts on November 30 (see p. 1046) interest in the future of the India Museum at South Kensington and the position of Indian studies in Great Britain will appear to have eclipsed the claims to attention of the lecturer's pioneer archæological work in Swat and Afghanistan. The importance of the question raised in his concluding remarks will be accepted in palliation. The anomalies and obstruction to development arising from the lack of cohesion and co-operation among the eight or ten organizations in London associated with Indian studies were characterized with wit and acumen by Mr. F. J. Richards, and echoed by each subsequent speaker in the discussion; while these criticisms were endorsed by Sir Richard Winstedt, who described briefly such steps, inadequate as they admittedly are, as it has been possible to take to meet these deficiencies in some measure by the provision of lectures in Indian art and archæology at the School of Oriental Studies, an institution, which, it is to be noted, already has wide commitments in other directions. On one point, which for some time past has been regarded with dismay among those 
interested in Indian cultural studies, Lord Zetland, who was in the chair, was able to reassure his audience. The risk, he said, that the collections of the India Museum might be dispersed, is at an end; and indeed, there is a prospect that the Indian sculptures at the British Museum (Bloomsbury) may be transferred to the India Museum at South Kensington.

THE discussion was an indication, if such were needed, of the existence of a strong body of instructed public opinion, restricted though it may be in extent, that a remedy must be sought for the present highly unsatisfactory position of Indian cultural studies. That there is need for an organized centre devoted to them may be argued on the ground of public policy in view of the future relations of Great Britain and India ; but it is also at the moment in pressing need of educational facilities in London. Contrary to the contention frequently advanced, $\mathbf{M r}$. Richards, from his experience as an honorary lecturer on Indian archæology in the University of London of some years' standing, was able to testify to the demand for instruction in this group of subjects; while the gratitude with which the rearrangement of the Indian collections at South Kensington on cultural lines has been acclaimed is a measure of the general appreciation of the possibilities of further systematic development in teaching and research. Whether provision of an organized centre of teaching and research can most suitably be made in connexion with the India Museum on the lines suggested in relation with the University of London is a matter for further consideration. The position of the Victoria and Albert Museum, of which the India Museum is at present a part, under the Board of Education, is anomalous. It presents difficulties, not insuperable, no doubt, which render comparison with other museums exercising teaching functions beside the mark, even though here, as in other of the national collections in London, the system of guide-lecturers exists for instructional purposes. This system might well be extended to meet needs of more advanced instruc. tion. In any event, no scheme of instruction can attain efficiency without the closest association with the collections and staff of the India Museum; nowhere else in Great Britain is there the systematic knowledge and the carefully graded series of specimens, for example, in pottery or beads, which may not be sufficiently spectacular for exhibition in public galleries, but are of the indispensable groundwork in instruction.

\section{Mr. E. Thurlow Leeds}

Mr. Edward Thurlow Leeds, keeper of the Ashmolean and the Department of Antiquities in the University of Oxford, whose election to a professorial fellowship at Brasenose College is announced, holds a position of distinction among archæologists for his carefully documented studies in Celtic and Saxon art and archæology. Mr. Leeds was educated at Uppingham and Magdalene College, Cambridge, on which foundation he was a scholar. $\mathrm{He}$ joined the staff of the Ashmolean as an assistant in the Department of Antiquities in 1908. Since the Great War, Mr.
Leeds's influence on the teaching of archæology at Oxford has been profound; and his appointment as keeper of the Ashmolean on the death of Dr. D. G. Hogarth was regarded as both opportune and a wellmerited recognition of his efforts in developing these studies in the University. Mr. Leeds was a vicepresident of the Society of Antiquaries of London in 1929-32 and Rhind lecturer in archæology in 1935, his lecture on "Early Saxon Art and Archæology" afterwards appearing in book-form. Mr. Leeds's responsibilities as keeper are now to be enlarged by the addition of an Institute of Egyptological Studies to the Museum. This is in accordance with a decree passed in Congregation of the University on November 29, which gives practical effect to the bequest, accepted in January last, by the late Prof. F. Ll. Griffiths, professor of Egyptology in the University of Oxford, and Mrs. Griffiths for that purpose. Although the Institute will form a department of the Ashmolean, it will be under the control of its own committee of management, a representative body.

\section{The Scientist and the Philosopher}

For his Friday evening discourse at the Royal Institution on December 2, Viscount Samuel took as his subject, "The Scientist and the Philosopher". $\mathrm{He}$ said that in the complicated civilization of the modern world a division of labour is necessary, but this is sometimes carried to excess. The separation between science and philosophy gives an example. This is not, as it might seem, a merely abstract and academic matter, remote from affairs. Action is ruled by ideas. Philosophies of some kind move the nations. Every land resounds with the tramp of armies, and the air throbs with the droning of their aircraft. Behind the armies are the dictators or the parliaments. Behind them are the political creeds, and behind the creeds are the philosophers who inspired them. Our age needs above all else a new synthesis of science and philosophy, together with religion, to supply the ideas that should guide the modern world. There are many things that philosophy should accept from science. Scientific workers in their turn may derive help from philosophy. They might be induced not to attribute physical qualities to human mental concepts, such as space; nor to assume that, because phenomena are out of reach of our means of observation, it follows that Nature does not determine them according to uniform laws. Two fundamental questions remain unsolved, and philosophers await the answers-from physics, the cause of gravitation, and from physiology the nature of thought. It is often said that these can never be solved; but if we view what has been the progress of knowledge between the stone age and now, further advances such as these are not inconceivable; they may indeed be close at hand. There is nowadays a marked convergence of science and philosophy. Let this develop and let religion, guided by reason and conforming to fact, take her place in the great synthesis; then man will feel at one with himself, will confront with new energy the confusions and perils that beset him, and be able to march with confident step into the future. 